\title{
THE DYNAMICS OF BACTERIAL CONTAMINATION OF THE GENITAL ORGANS IN SOWS DURING THE PUERPERIUM
}

\author{
Z. VLČEK, R. SVOBODOVÁ. \\ Department of Farm Animal Reproduction and Surgery, University \\ of Veterinary Science, 61242 Brno
}

Received October 11, 1979

\begin{abstract}
Vlček Z., R. Svobodová: The Dynamics of Bacterial Contamination of the Genital Organs in Sows During the Puerperium. Acta Vet. Brno, 49, 1980: 231 -236.

In 47 primiparous Large White sows, slaughtered at various times during the puerperium, the extent, degree and dynamics of bacterial contamination of the genital organs, was ascertained. The frequency of bacteria in the cranial parts of the sexual routes - the oviducts and the uterus - was markedly lower than in the caudal sections - the vagina and the vaginal vestibulum.

The dynamics of bacterial contamination of the uterus showed a declining trend during the puerperium, and the number of bacteria was soon reduced and eliminated. Temporarily appearing saprophytic species were dominant in the microflora, as well as facultative pathogenic bacterial species, and sporadically there were isolated pathogenic species.
\end{abstract}

Reproduction, pig, puerperium, genital tract, bacterial content.

The increase of the large-scale rearing of pigs is conditioned by the scientific management ol production, requiring intense study and an all-round extension of knowledge of physiologicaf and pathological processes in the genital organs, which influence reproduction.

In our studies we have directed our attention to the puerperium, which is a relatively little studied subject, yet, at the same time for the further utilizing of breeding, a very important section of the reproductive cycle of sows (Kudláč et al. 1977a; Kudlác et al. 1977b; Kudláč 1977). In the presented paper we in estigated the relation of one of the environmental factors - the bacterial flora contaminating the genital routes - to the course of the puerperium.

It must be stated that the problem of the part of bacterial contamination or infection played in the disturbances of reproduction in sows has as yet not been sufficiently investigated. Most papers have dealt with the infectious causes of abortion (Aamdal 1970; Beninghaus et al. 1974: Jacob 1974; Vačev and Djakov 1970). The occurrence of microbes in the genital organs of sows in the puerperium were considered especially in connection with bacterial infections and intoxications, constituting a part of the MMA syndrome (Fiebinger et al. 1975; Jones 1971; Mohai 1976; Wesemeier et al. 1975). Other authors primarily concerned themselves with the study of bacterial fllora as etiological factors of the disturbances of fertility in sows (Doty and Vorhies 1971; McErlean 1969; Fikejz 1977; Hájovský and Gamčík 1966; Khan 1972; Vlček 1977). Also papers on bacteria in the genital tracts of sows in other phases of the physiological reproductive cycle are isolated (Zaki-Syed and Manjrekar 1970; Olejník 1975). Other than in the situation with cows, where there are numerous papers, we found no mention of a protective system of the genital organs against microbial infection and the dynamics of bacterial contamination of the genitals in the course of the physiological puerperium. 


\section{Materials and Methods}

We examined the genital organs of 47 primiparous sows of White Thoroughbred Breed from several litters of one flock, weaned under uniform conditions. The sows farrowed 8-13 piglets (about 9,48 piglets) in uncomplicated births. They were slaughtered at various periods of the puerperium, i. e. within 1-24 days after farrowing; in five cases on the first days after the weaning of the piglets. Undamaged sexual organs were gained and were judged macroscopically; cultivation was carried out on meat-pepton agar, enriched with ram erythrocytes from individual sections from the genital tracts - from the vaginal vestibulum, the vagina, the external and internal os of the uterine cervix, the uterine horns and oviducts. Incubation was carried out in aerobic environment at $37^{\circ} \mathrm{C}$ for 48 to $72 \mathrm{hrs}$.; identification of the subculture at the Department of Epizootiology and Microbiology, University of Veterinary Science. The number of bacteria was classified according to the following scheme:

$\mathrm{S}=$ bacteriologically sterile

$I=$ isolated colonies not exceeding 6 in the Petri dish

II $=$ medium contamination up to 20 colonies

III $=$ greater numbers of colonies

Investigations were directed to the establishment of the extent, degree, dynamics and qualitative composition od bacterial contamination.

\section{Results and Discussion}

At evaluation of the extent and degree of bacterial contamination of the genital organs of sows in the puerperium, we found the greatest number of bacteria in the caudal portions of the sexual routes, $i$. e. in the vaginal vestibulum and the vagina. Table 1 shows that the contamination of 3rd degree was evidenced in the vaginal vestibulum of $36,58 \%$ sows and in the vagina of $21,73 \%$. In a further $26,82 \%$ resp. $21.73 \%$ sows, there was contamination of the 2nd degree so that including isolated colonies a total of $68,29 \%$ and $63,04 \%$ positive results were found. Contrary to this the contamination of the deeper sections of the genital tracts was definitely smaller - a large number of bacteria (3rd degree) was found in the external os of the uterine cervix in $21,27 \%$ sows, but only in the internal os of the uterine cervix in $10,63 \%$, and in the uterine horns $8,51 \%$. The oviducts were found to be bacteria-free during the whole course of the puerperium in the greater majority of the sows, and in positive cases concerned a finding of isolated colonies. A reduction of bacterial contamination from the caudal to the deeper sections of the genital tracts is evident from the relation of positive and negative findings. In the caudal sections of the genital tracts the number of positive findings prevailed over the negative. However, starting from the external os of the uterine cervix the number of positive findings of bacteria

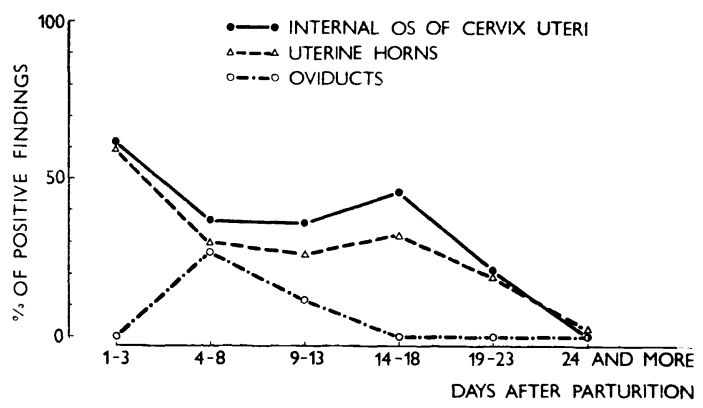

Fig. 1 was smaller than the number of negative findings.

From the evaluation of the dynamics of the occurrence of bacteria in the sexual organs in the process of involution, it is obvious that findings of a larger number of bacteria in the uterine horns appeared primarily in the first days of the puerperium, and the situation altered diametrically during the following course of the puerperium. As may be seen 
from Fig. 1 and 2, the dynamics of bacterial contamination of the uterine cervix and uterine horns were influenced by the time after parturition, and exhibited a distinctly descending trend during the puerperium. A relatively large number of bacteria which was ascertained in the majority of sows during the first three days after farrowing (the internal os of the uterine cervix and the uterine horns were positive in $57,14 \%$ cases), was reduced between the 4 th -8 th day after farrowing, and was essentially liquidated during the following course of the puerperium. Similarly a number of cases of contamination of the external os of the uterine cervix was reduced from the original $100 \%$ in the first three days after farrowing to a third, and then remained at essentially the same level. However, this trend was not apparent in the initial and final sections of the genital tracts. The findings of bacteria in the oviducts were sporadic during the whole course of the puerperium with the exception of a trifling increase between the 4th-8th day after farrowing, so that evaluation of the dynamics of the occurrence of bacteria is problematic. In the caudal sections of the reproductive tract - in the vagina - the number of bacteria remained at the same level during the whole of the puerperium and actually increased in the vaginal vestibulum in time. This phenomenon can be explained by the fact that the caudal sections of the genital routes are exposed to constant contamination by microbes from external environment, which is most contaminated by a large number of bacteria depending upon the level of hygiene and the microclimate of the farrowing house. Thus the caudal sections of the genital routes are obviously as in cattle, and probably in other mammals, furnished with a highly effective defensive system against bacterial contamination and infection, and are also characterized by a marked resistance to bacterial infections. A similarly rapid involution of the uterus and the renewal of functional homeostasis needed for a further gravidity is necessarily dependent upon the ability of speedily reducing and liquidating the bacteria in the deeper sections of the genital routes.

By investigation of the qualitative composition of the bacterial Hora, occurring in the sexual organs of sows with an uncomplicated course of the puerperium, we found, as did Olejník (1975), Vlček (1977), Hájovský and Gamčík (1966), Zaki-Syed and Manjrekar (1970) a high prevalence of saprophytic microbial species or species, which may on occasion be pathogenic, and only sporadically pathogenic species. Microbial species cultivated form the uterine cervix and the uterine horns were essentially identical with the microbial species occurring in the vagina and in the vaginal vestibulum. They were mostly viridating (alpha) streptococci, enterococci, enterobacteria, especially of the genus Citrobacter, saprophytic species of the genus Corynebacterium, and Micrococcus. Staphylococcus aureus was identified in isolated cases. The microflora of the vagina, and still more of the vaginal vestibulum were more varied and more extensive, especially in the case of species pointing to contamination from external environment (species of the genus Bacillus, Brevibacterium, Sarcina and Proteus, and other 


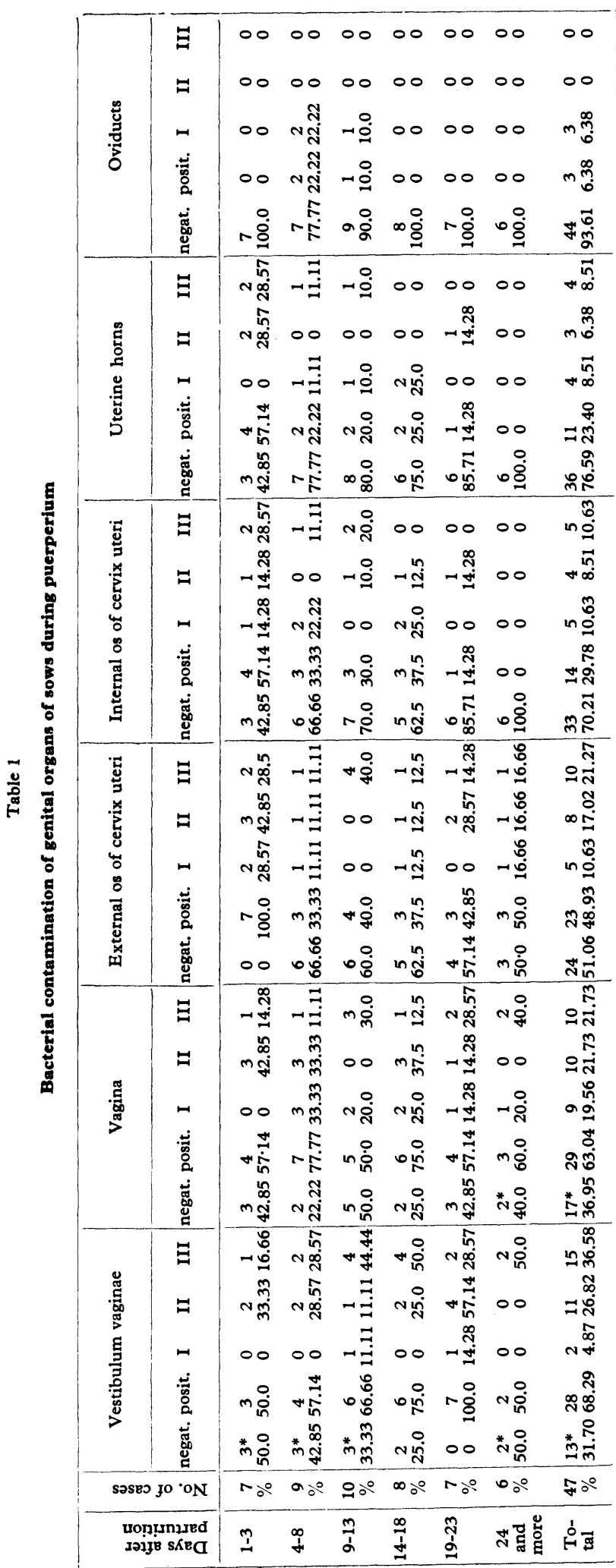


saprophytic strains, not closely identified cocci, bacteria and fungi). Obviously the recorded microbial spectrum is not complete, for microbes with specific claims to environment could not be proved by the methods used.

\section{Dynamika bakteriální kontaminace pohlavních orgánů prasnic v puerperiu}

U 47 primiparních prasnic bílého ušlechtilého plemene, porážených v různých obdobích puerperia, byl zjištován rozsah, stupeň a dynamika bakteriální kontaminace pohlavních orgánů. Výskyt bakterií $\mathrm{v}$ počátečních úsecích pohlavních cest - vejcovodech a děloze - byl podstatně menší než $\mathrm{v}$ konečných úsecích pochvě a poševní předsíni.

Dynamika bakteriální kontaminace dělohy vykázala během puerperia sestupný trend a množství bakterií bylo záhy redukováno a likvidováno. $\mathrm{V}$ mikrofloře převládaly ubikvitárně se vyskytující saprofytické a příležitostně patogenní druhy bakterií a jen ojediněle se vyskytly patogenní druhy.

\section{Динамика бактериальной контаминащии половых органов свиноматок в послеродовом периоде}

У 47 первоопоросок свиноматок белого перодистого племени, отправляемых, на убой в разный период после опороса, проводились исследования масштаба, степени и динамики бактериальной контаминации половых органов. Наличие бактерий в начальных участках половых органов - в яйцеводах и матке - было существенно меньше по сравнению с конечными участками - влагалище и предвлагалище.

Динамика бактериальной контаминации отличалась в послеродовом периоде нисходящей тенденщией и количество бактерий незадолго уменьшилось и было ликвидировано. Преобладающими в микрофлоре стали находящиеся везде сапрофитические бактерии и изредка патогенные виды бактерий; лишь в отдельных случаях имели место патогенные виды.

\section{References}

AAMDAL, J.: Abortion in sows. Acta vet. scand., 11, 1970: 390-393.

BENINGHAUS, T. - FEJES, J. - PAUEROVÁ, H.: Rozbor príčin abortov a predčasných pôrodov so zretelom na prítomnost' infekčného agens. Veterinářství, 24, 1974: 57-59.

DOTY, M. K. - VORHIES, M. V.: The role of the Streptococcus equisimilis in swine infertility, fetal death and abortion. Iowa St. Univ. Vet., 33, 1971: 88-91.

McERLEAN, B. A.: Abortion and infertility in swine. Irish vet. J., 23, 1969: 113-118.

FIEBINGER, K. - KAISER, H. - TRAEDER, W.: Ein Beitrag zur vorsorglichen Behandlung des Metritis-Mastitis-Agalaktie-Syndroms der Sauen. Tierärztl. Umschau., 30, 1975: 251-256.

FIKEJZ, B.: Zhodnocení intravitálních a postmortálních nálezů u diagnosticky odporažených prasnic vyřazených pro poruchy fertility. Sborník ref. IV. Přibylovy dny Brno, 1977: 38.

HÁJOVSKÝ, T. - GAMČÍK, P.: Výskyt, pričiny a možnosti prevencie prenatálnych strát u prasníc. Veterinářství, 16, 1966: 394-399.

JACOB, W. K. - BIERWIRTH, G. - KÖTSCHE, W.: Eine Auswertung der Ergebnisse bakteriologischer Untersuchungen abortierter Schweinefeten. Mh. Vet. Med., 29, 1974: 468-471 . 
JONES, J. E. T.: Reflections on post-parturient diseases associated with lactational failures in sows. Vet. Rec., 89, 1971: 72-77.

KHAN, M. W. - ROSS, R. F.: Antigenic type-specifity of swine isolates of Streptococcus equisimilis. Canad. J. comp. Med. Ottawa, 36, 1972: 256-260.

KUDLÁĆ, E. - GROCH, L.: Morphologische Veränderungen an Ovarien und Uterus bei Sauen im Puerperium. Zuchthygiene (in press)

KUDLÁĆ, E. - VLČEK, Z. - STUDENČÍK, B. - SVOBODOVÁ, R.: Morfologické změny a obsah bakterií v pohlavním ústrojí prasnic během puerperia. Sborník ref. IV. Přibylovy dny Brno, 1977: 35.

MOHAI, I.: Tapasztalatok az MMA-syndroma megelözesére különös tehintettel az Ergometrin inj. használatára. Mag. Állatorv. Lap., 31, 1976: 559-560.

OLEJNÍK, P.: Studie bakteriální kontaminace pohlavních orgánů prasnic. Ref. SVK, Brno, 1975.

VAČEV, B. - DJAKOV, L.: Etiologija na abortite po svinete. Vet. sbirka Sofija, 67, 1970: 10-12.

VLČEK, Z.: Význam bakteriologického vyšetření pohlavních orgánủ při diagnostice poruch reprodukce prasnic. Reprodukce a genetika hosp. zviřat, 1977: 28-31.

WESEMEIER, H. - HÖLZEL, W. - VÖLKER, H.: Pathologische und mikrobiologische Befunde bei puerperal gestörten Sauen - ein Beitrag zur Pathogenese der Puerperalerkrankungen. Mh. Vet. Med., 30, 1975: 814-820.

ZAKI SYED - MANJREKAR, S. L.: Normal bacterial flora of the porcine uterus. Indian vet. J., 47, 1970: 4-7. 